http://kitaibelia.unideb.hu/

ISSN 2064-4507 (Online) • ISSN 1219-9672 (Print)

(C) Department of Botany, University of Debrecen, Hungary

25(2): 242-246.; 2020

DOI: $10.17542 /$ kit. 25.242

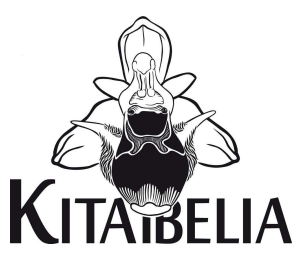

Apró közlemény / Short communication

\title{
Leucojum vernum a Súri-Bakonyalján és a faj Bakony- vidéki elterjedésének áttekintése
}

\author{
BAUER Norbert \\ Magyar Természettudományi Múzeum, Növénytár, \\ H-1089, Budapest, Könyves K. krt. 40.; bauer.norbert@nhmus.hu

\section{Leucojum vernum at the Súri-Bakonyalja and overview of its distribution in the Bakony Region}

\begin{abstract}
In Hungary Leucojum vernum is considered a plant species of montane character, distributed predominantly in Transdanubia. Apart from some isolated localities (Zalaszántó Basin Mts, Tapolca Basin), the occurrences of the species are mainly confined to the region "Magas Bakony" and its periphery within the Hungarian Middle Mts. In the spring of 2020 a large population was discovered by the author in the region "Súri-Bakonyalja", which significantly expands the known local distribution range of the species. The new population, together with other phytogeographically significant species (e.g. Anemone nemorosa, Corydalis intermedia, Veratrum album), was found in a poorly explored valley system (Kisbér village: Báró-erdő). Based on all literature and herbarium records, the local distribution range of L. vernum is surveyed.
\end{abstract}

Keywords: Amaryllidaceae, distribution, legally protected species, Transdanubia

Összefoglalás - A Leucojum vernum Magyarországon dunántúli elterjedési súlypontú, montán karakterű faj. A Magyar-középhegységben ismert állományainak zöme a Magas-Bakonyra és nyugati peremvidékére korlátozódik, néhány egyéb, szigetszerű előfordulással. (Zalaszántó-medence; Tapolcaimedence). A faj regionális elterjedési képét számottevően módosítja, hogy 2020 tavaszán jelentős egyedszámú populációja került elő Súri-Bakonyalja egy eddig kevésbé kutatott, más növényföldrajzi szempontból fontos növényfajokat (pl. Anemone nemorosa, Corydalis intermedia, Veratrum album) is őrző völgyrendszerében. A populáció előkerülése apropóján a dolgozatban áttekintésre kerül a faj regionális elterjedési képe, a térségből származó herbáriumi és publikált adatainak feldolgozása.

Kulcsszavak: Amaryllidaceae, Dunántúl, elterjedés, védett faj

A Leucojum vernum L. közép-európai faj (MEuSEL et al. 1965), Magyarországon kifejezett nyugat-dunántúli elterjedési súlyponttal, az ország északkeleti peremvidékén a Beregi- és Szatmári-sík, valamint a Bodrogköz térségében ismert még néhány spontán előfordulása (vö. FARKAS 1999, BARTHA et al. 2020). A Magyar-középhegységbe a Bakony-vidék területén lép be, előfordulásainak zöme e középtájon belül is a Magas-Bakonyban („Öreg-Bakony”) és nyugati peremvidékének völgyeiben található. A kifutó patakvölgyek mentén a DevecseriBakonyalján is megjelenik. Szigetszerű előfordulásai a Keszthelyi-hegység peremén is ismertek (ld. alább). A tájnevek említése az alábbiakban DövÉNYI (2010) tájmonográfiáját követi, de az elterjedési kép megértését még inkább segítő, növényzeten alapuló vegetációs középtáj-beosztás (MOLNÁR et al. 2008) szerinti hovatartozást is jelzem zárójelben. 
2020. április 11-én a Leucojum vernum többszázas nagyságrendű populációja került elő a Súri-Bakonyalján (MolNÁr 2008 beosztásában: Központi-Bakonyalja), Kisbér határában (KEF: 8574.3). Itt a növény a Fekete-víz-ér egy oldalvölgyének középső és főleg felső szakaszán fordul elő, a Báró-erdőben. Élőhelye a völgyben egy időszakos vízfolyás mentén található. A meder 2020 tavaszán nagyrészt száraz volt, de a forrás körül, egy negyedhektárnyi területen üde, tocsogós égeres található. Ebben a foltban él a tavaszi tőzike itteni állományának zöme, de egy-egy ponton a völgy alsóbb szakaszán, a gyertyános-tölgyesben is felbukkan. A völgy és a Kisbér-Bakonyszombathely-Ácsteszér közötti erdőtömb (Homokházi-erdő, Báró-erdő, Szarvas-hegy, Fekete-víz-ér völgye) erdei nagyrészt elszegényedett, homogenizálódott aljnövényzetű tölgyesek (és akácosok), de néhány ponton kifejezetten fajgazdag, értékes erdőfoltok is vannak. A Súri-Bakonyalja kavicstakaróján kialakult mezofil erdőkben, az alacsony tengerszint feletti magasság ellenére jónéhány mezofil erdei montán elem, ill. láperdei faj fennmaradt, néhányukat BAUER (2007) is említi. Különösen a forrásos égeserek (Cardamine amara L., Cerastium sylvaticum Waldst. et Kit., Crepis paludosa (L.) Moench., Veratrum album L.), és a gyertyános-tölgyesek (Corydalis intermedia (L.) Mérat, Lilium martagon L., Melica nutans L., Silene dioica (L.) Clairv.) őriznek a bakonyaljai tájban már ritka fajokat. Ezek sorában már nem olyan meglepő a Leucojum vernum előkerülése. A KisbérBakonyszombathely-Ácsteszér erdőtömb növényföldrajzi szempontból egyik legfontosabb (tömegesen előforduló) faja, a hazánkban szintén nyugat-dunántúli súlypontú Anemone nemorosa L., amely a Bakony-vidékre csak a Súri-Bakonyalján és Keszthelyi-hegység északi, bazalthegyein (KEF: 9069.3: Zalaszántó: Kovácsi-hegy, Kovácsi-kút, Kovácsi-patak-v., Várotthegy; Nagygörbő: Kő-oldal, Hárs-gödör) lép be.

A Leucojum vernum Súri-Bakonyalján előkerült populációja apropóján és a faj hazai elterjedési térképeinek (vö. FARKAS 1999, BARTHA et al. 2020) hiányosságai miatt igyekeztem tisztázni pontos regionális elterjedési képét. Áttekintettem herbáriumi (a BP-herbárium, valamint az MTM Bakonyi Természettudományi Múzeuma /alább: Zirc/ és Mátra Múzeuma /Gyöngyös/) és publikált adatait, valamint összeállítottam aktuális bakony-vidéki elterjedési térképét (1. ábra).

Herb.: Magas-Bakony („Öreg-Bakony”): 8771.2 - BAUER N., 2001.03.15., Bakonyjákó: Pápai-Bakonyérvölgye, az Asztal-völgy közelében (BP); BAUER N., 2017.03. 15., Ugod: Macskalukas-árok (BP). 8771.3 BAUER N., 2012.04.05., Döbrönte: Köves-patak mente (BP). 8771.4 - TALLós P., 1956.04.22., Bakonyjákó: „Járiföld, ... in alneto" (Herb.: Zirc); BAUER N., 2001.03.15., Bakonyjákó: Cseke-bükk (BP); BAUER N., 2017.03.18., Bakonyjákó: Asztal-völgy (BP); BAUER N., 2017.03.18., Bakonyjákó: Járiföld, Jári-patak völgye (BP). 8772.1 - Boros Á., 1954.04.05., „,ad Hubertus-lak ad vallem Somberek-séd” (BP); Boros Á., 1954.05.17., Nagyförtés-árok versus Hubertuslak prope Ugod" (BP); JÁVORKA S., MAYER A. \& CSAPODY V., 1955.04.02., Ugod alatt: Nagyförtés árok és Hubertus-lak felett” (BP); Boros Á., 1954.04.03., „Molnárkút-árok ad Gerence-puszta pr. Bakonybél” (BP); VAJDA L., 1954.04.03., „Molnárkút-árok” (BP); TALLós P. s.d., „Molnárkút-árok” (Herb.: Zirc); GoTTHÁRD J., 1977, Somberek-séd, Hubertus-lak (Herb. Gyöngyös; vö. BÁNKÚTI 1998); Galambos I., 1979.03.23., Ugod: Hubertlak (Herb.: Zirc); BAUER N., 2003.03.10., Ugod: Szarvas-kúti-árok (BP); BAUER N., 2013.04.11., Ugod: Szarvas-kút-árok (BP); BAUER N., 2017.03. 15., Ugod: Nagy-förtési-árok (BP); BAUER N., 2017.03. 15., Ugod: Ingesbika-árok (BP). 8871.1 - VILÁGHY Andreas, 1928.03.29., Farkasgyepü „in Kemencerét” (BP); BoROS Á. 1951.02.18., Farkasgyepü, „ad Uj-malom vallis rivi Kövesd-patak” (BP); PAPP J., 1951.02.18., Farkasgyepü (BP); BÁNó L., 1951.03.11., Farkasgyepü, „nyirkos patakpart” (BP); KÁRPÁTI Z., 1951.03.11., Farkasgyepü (BP); BAUER N., 2008.05.10., Farkasgyepü: Köves-patak völgye (BP). 8672.4 - JÁVorKA S. \& VAJDA E., 1928.03.10., „vallis Hódosér versus pag. Porva” (BP); VAJDA L. 1928.03.11., Hódosér (BP); BAUER N., 2017.03. 22., Bakonyszentlászló: Hódosér-völgy (BP). Keszthelyi-hegység: 9169.2 - BAUER N., 2015.04.19., Zalaszántó: Bándi-mező, Nagy-réti-patak ártere (BP). Tapolcai-medence: 9170.1 - BAUER N., 2015.03.15., Lesencetomaj: Lesence-patak ártér („spontanea?”) (BP).

Irod.: Magas-Bakony („Öreg-Bakony”): 8672.4 - Hódosér (PILlitz 1910); Hódoséri-völgy (PolgÁR 1935); Hódosér (Bartha ap. RÉDL 1942). 8771.2 - Iharkúti Hosszúrét (RÉDL 1934); Öreghegyen a forrás 
környékén (RÉDL 1940); Bakonyjákó: Pápai-Bakonyér-völgye (BAUER 2004). 8771.4 - Bakonyjákó: Járiföld (TALLós 1959); Bakonyjákó: Cseke-bükk (BAUER 2004); Bakonyjákó: Herman-kút; Németbánya: Bittva-patak mente; Farkasgyepü: Bittva-patak partján (BAUER ined.). 8772.1 - Gerencepuszta, Molnárkútárok (RÉDL 1940); Hubertlak, Péterrét (RÉDL 1940); Ugod: Nagyförtés-árok, Ingesbikarétárok, Kisgyökeres-árok (FEKETE et al. 1961); Ugod: Szarvaskút-árok, Hamuházi-árok (BAUER 2004). 8871.1 - Farkasgyepü: Kövesdpatak szép völgyében (DoRNYAY 1927); Farkasgyepü: Kemencerét (RÉDL 1930, 1942); Kövesd-patak ... prope Farkasgyepü (Boros 1954); Farkagyepü: Köves-patak völgy, kiszélesedő völgytalpán magaskórósban, a Vadászháztól D-re; (BAUER 2009). Devecseri-Bakonyalja: 8870.2 - Noszlop: Becsei-erdő (TALlós 1959); 8871.1 - Noszlop: Hajagos-patak völgye (BAUER 2009). Súri-Bakonyalja: 8574.3 - Kisbér: Báró-erdő névtelen völgye, a Fekete-víz-ér oldalvölgye (BAUER ined.). Keszthelyi-hegység (Zalaszántói-medence): 9063.3 - nedves réteken a bazsai (bazsi) határban (SZÉP 1890); 9169.1 - Zalaszántó „Vár-berek” (KEVEY 1993); Zalaszántó (FARKAS 1999).

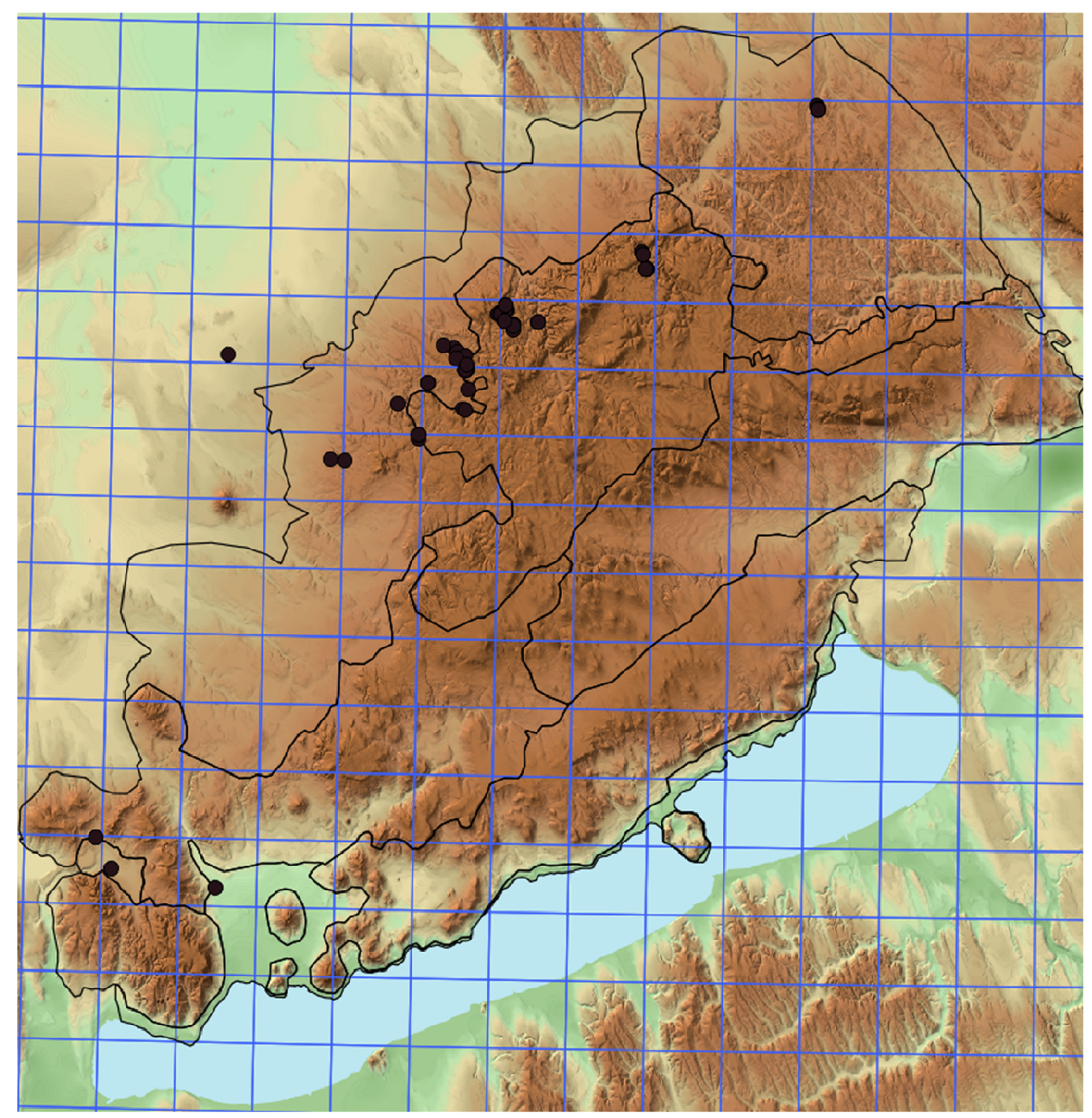

1. ábra A Leucojum vernum elterjedése a Bakony-vidéken, a vegetációs középtájak határaival Fig. 1 Local distribution range of Leucojum vernum in the Bakony Region 
A Leucojum vernum-ot a Bakony-vidék területén elsőként Szép Rezső publikálta Bazsi mellől („a bazsai határban”) (SzÉP 1890), a Keszthelyi-hegység északi pereméről. A szűkebb értelemben vett Bakonyban PILLITZ (1910) találta a Hódos-ér völgyben. Ezt követően napjainkig szépen bővültek előfordulási adatai (RÉDL 1930, 1940, 1942, POLGÁR 1935, BoRos 1954, FEKETE et al. 1961, KEVEY 1993, BAUER 2004, 2009). Bakony-vidéki elterjedési mintázatán egy nagyon egyértelmű magas-bakonyi súlypont látható. Legtöbb és legerősebb állománya alig néhány település üde, forrásos/patakos völgyeire koncentrálódik, égeresekben, olykor bükkösökben él. A Devecseri-Bakonyalja (MolNár et al. 2008 beosztásában: NyugatiBakonyalja) területére csak a Magas-Bakonyból (MoLNÁR et al. 2008 beosztásában: KözpontiBakony) kifutó völgyekben jut el, néhány ponton. SzéP (1890) Bazsiból származó adatának közelében, de már a Keszthelyi-hegység bazalthegyeitől délre, a Zalaszántói-medencében KEVEY (1993) találta, jelen közleményben egy-két közeli előfordulási adattal itt is sikerült bővíteni az ismert előfordulások sorát. Hasonlóan szigetszerű, őshonos előfordulás lehet a Kisbér határából, jelen dolgozatban közölt állomány a Súri-Bakonyaljáról.

Néhány, a térségből származó publikált Leucojum-adat tisztázást, pontosítást igényel. BORBás (1900) flóraművében Keszthely vidékéről idézi Szenczy, Hutter és Wierzbicki kéziratában (SZENCZY et al. 1842) szereplő Leucojum aestivum L. adatot. A két hazai Leucojum-faj hazai elterjedési képe (BARTHA et al. 2020), a korábbi SzÉP (1890) és a későbbi zalaszántói Leucojum vernum adatok alapján inkább feltételezhető, hogy a Borbás által idézett tőzikeadat is tavaszi tőzikére vonatkozhat.

RÉDL (1942) flóraművében az addig ismert Leucojum vernum adatok felsorolásában feltúnik egy „Nemesszalók-Vinár” (Sági A. ap. RÉDL 1942) lelőhely. Ez a Kisalföldről, a Marcalmedencéből származó adat bizonytalan. Habár TALLós (1959) a közelből, „Nagyalásony: Kispodár puszta" lelőhelyről közöl Leucojum vernum adatot, nem zárható ki, hogy Sági bizonyítópéldány nélküli adata inkább a Leucojum aestivum taxonra vonatkozhat, amely szintén ismert a Marcal-medence és Bakonyalja közeli peremvidéke néhány pontjáról (ld. SzoDFRIDT \& TALLÓS 1965, BAUER 2004).

A herbáriumi adatok összegyűjtésében Sinigla Mónika (Zirc), Kovács Tibor (Gyöngyös) és Takács Attila voltak segítségemre, munkájukat köszönöm.

\section{Irodalom}

BÁNKUTI K. (1998): A Mátra Múzeum herbáriuma - a Gotthárd-gyûjtemény I. (Pteridophyta, Gymnospermatophyta, Monocotyledonopsida). - Folia Historico Naturalia Musei Matraensis (199899) 23: 103-141.

BARThA D., BÁN M., Schmidt D. \& TiborCz V. (2020): Magyarország edényes növényfajainak online adatbázisa (https://floraatlasz.uni.sopron.hu) - Soproni Egyetem, Erdőmérnöki Kar, Növénytani és természetvédelmi Intézet (hozzáférés: 2020.09.01.)

BAUER N. (2004): Florisztikai adatok a Bakonyból és a Bakonyaljáról II. - Kitaibelia 9(1): 187-206.

BAUER N. (2007): Florisztikai adatok a Bakonyból és a Bakonyaljáról III. - Kitaibelia 12(1): 41-51.

BAUER N. (2009): Florisztikai adatok a Bakonyból és a Bakonyaljáról IV. - Kitaibelia 14(1): 16-29.

Borbás V. (1900): A Balaton tavának és partmellékének növényföldrajza és edényes növényzete. - A Balaton tudományos tanulmányozásának eredményei II.2. szakasz, Budapest, 431 pp.

Boros Á. (1954): Florisztikai közlemények IV. - Botanikai Közlemények 45(3-4): 247-250.

DoRNYAY B. (1927): Bakony. - Részletes Magyar Utikalauzok II. kötet, Budapest, 424 pp.

DöVÉNYI Z. (szerk.) (2010): Magyarország kistájainak katasztere. - MTA Földrajztudományi Kutatóintézet, Budapest, 876 pp.

FeKete G., Majer A., Tallós P., VidA G. \& Zólyomi B. (1961): Angaben und bemerkungen zur Flora und Pflanzengeographie des Bakonygebirges - Annales historico-naturales Musei nationales hungarici 53: 241-253. 
KEVEY B. (1993): Adatok Magyarország flórájának és vegetációjának ismeretéhez VI. - Botanikai Közlemények 80 (1): 53-60.

MEUSEL H., JÄGER E. \& WEINERT E. (1965): Vergleichende Chorologie der zentraleuropäischen Flora. Band I. Karten. - Gustav Fischer Verlag, Jena, pp. 1-258.

Molnár Cs., Molnár Zs., Barina Z., Bauer N., Biró M., Bodonczi L., Bölöni J., Csathó A. I., Csiky J., DeÁK J. Á., Fekete G., Horváth A., Juhász M., Kállayné Szerényi J., KirÁly G., Magos G., Máté A., Mesterházy A., Molnár A., Nagy J., Óvári M., Purger D., Sramkó G., SzÉnÁsi V., Szmorad F., Tóth T. \& Virók V. (2008): Vegetation-based landscape-regions of Hungary. - Acta Botanica Hungarica 50 (Suppl.): 47-58.

Pillitz B. (1910): Pótlások Veszprém vármegye növényzetéhez. - Veszprémvármegyei Múzeum Kiadványai II., Veszrém, pp. 140-167.

PoLGÁR S. (1935): A Cuhavölgy növényzeti viszonyai. - Győri Szemle 6: 149-160.

RÉDL R. (1934): Képek a Bakony flórájából III. - Veszprémi kegyestanítórendi Róm. Kat. Gimnázium Értesítője 1933-34: 26-33.

RÉDL R. (1940): Képek a Bakony flórájából VII. - Veszprémi kegyestanítórendi Róm. Kat. Gimnázium Értesítője 1939-40: 36-40.

RÉDL R. (1942): A Bakonyhegység és környékének flórája. - Magyar Flóraművek V., Veszprém, 159 pp.

SZENCZY I., HuTTER M. \& WieRzBicky P. (1842): Elenchus Plantarum in Territorio Keszthelyensi. - MTM Tudománytörténeti Gyűjtemény, III.-4.7.10., 13 pp.

SzÉP R. (1890): Sümeg határának edényes növényei. Plantae vasculares regionis Sümeghiensis. - $A$ Sümegvárosi róm. kath. elemi fiu- és leányiskola XXXII. értesítője. Pp. 3-29.

SzODFRIDT I. \& TALLóS P. (1965): Újabb adatok a Dunántúl flórájához. - Botanikai Közlemények 52(1): 2328.

TALLós P. (1959): Növényföldrajzi és florisztikai adatok a Dunántúlról. - Botanikai Közlemények 48(12): 77-80.

Beérkezett / received: 2020. 09.14. • Elfogadva / accepted: 2020. 09. 16. 